\title{
Phenotypic plasticity in the life history of the mangrove snail Cerithidea scalariformis
}

\author{
Nancy F. Smith ${ }^{1, *}$, Gregory M. Ruiz ${ }^{2}$ \\ ${ }^{1}$ Galbraith Marine Science Laboratory, Eckerd College, 4200 54th Avenue South, St. Petersburg, Florida 33711, USA \\ ${ }^{2}$ Smithsonian Environmental Research Center, PO Box 28, Edgewater, Maryland 21037, USA
}

\begin{abstract}
Although phenotypic variation is commonly observed among populations, the relative contribution of genetic and environmental conditions to phenotypic expression, including life history traits, is often unresolved. We measured characteristics of several isolated populations of the mangrove snail Cerithidea scalariformis across 2 habitat regimes (exposed marsh and forested mangrove marsh) and found considerable variation in all population characteristics over a 2 yr period. Differences existed among populations in density and individual size, and snails in the forested marsh were significantly larger than those in the exposed marsh. In a reciprocal transplant experiment, we tested the extent to which phenotypic plasticity may contribute to observed population differences in size and several other attributes. Regardless of source, snails maintained in the exposed marsh exhibited faster growth, earlier maturation, greater size, and higher rates of parasitism than snails in the forested marsh. Our results demonstrate that considerable plasticity in demographic traits exists in $C$. scalariformis across the highly variable range of conditions in coastal wetland habitats. The proximate and ultimate cause of plasticity in these snails, as well as any associated advantages, remain to be tested.
\end{abstract}

KEY WORDS: Cerithidea scalariformis · Growth · Life history variation · Parasitism · Phenotypic plasticity $\cdot$ Reciprocal transplant experiment $\cdot$ Shell morphology

Resale or republication not permitted without written consent of the publisher

\section{INTRODUCTION}

Species often exhibit temporal and spatial variation in their morphological, life history, and behavioral traits. Comparative studies among populations have been used to explore mechanisms underlying such variation, including a broad range of environmental and biotic factors (Lewis \& Bowman 1975, Brown 1979, 1985, Parry 1982, Reznick \& Endler 1982, Fletcher 1984, Trussell \& Smith 2000). A fundamental focus of this research has been to understand the relative contributions of genotype and environment to observed differences among populations (Struhsaker 1968, Janson 1982, Berven \& Gill 1983, Travis 1983, Fletcher 1984, Brown 1985, Trussell 1997, Lively et al. 2000). In recent years, it has become evident that phenotypic plasticity, or the capacity of an organism to produce phenotypic changes in response to environmental cues, is more common than initially expected.
The potential importance of plasticity as an adaptive response to environmental heterogeneity has been widely recognized in a variety of plants and animals (e.g. Bradshaw 1965, Harvell 1984, Lively 1986a, Schlichting 1986, Stearns 1989a, Trussell 1997). Terrestrial, freshwater, and marine gastropods have been especially useful for exploring mechanisms of intraspecific variation for multiple reasons. First, they often inhabit heterogeneous environments and exhibit conspicuous variation in morphology, life history, and behavior (Sutherland 1970, Roberts \& Hughes 1980, Fletcher 1984, Brown 1985, Johannesson et al. 1997, Trussell \& Smith 2000, Rolan et al. 2004). Second, gastropods are particularly conducive to manipulative field experiments, due to their high abundance and relatively sedentary nature. Intraspecific variations in gastropod life history and morphology have frequently been shown to result from direct phenotypic responses to environmental variables, including physical and 
chemical properties of water, food availability or quality, and predation pressure (Moore 1936, Phillips et al. 1973, Spight 1973, Lewis \& Bowman 1975, Underwood 1979, Janson 1982, Trowbridge 1994, Behrens Yamada et al. 1998). Some evidence also exists for a genetic component to variation in gastropod traits (Struhsaker 1968, Janson 1982, Janson \& Ward 1984, Day \& Bayne 1988), although there have been few formal genetic studies quantifying heritability and genetic variance in observed character traits.

Phenotypic response to environmental conditions is often related to levels of gene flow among populations, which in turn are influenced by species' dispersal abilities (Levins 1968, Palumbi 1995, Parsons 1998). Species with limited dispersal, such as direct developers, can have restricted gene flow. Consequently, when little or no gene flow occurs between adjacent sites, genetic differentiation among populations may result (Day \& Bayne 1988, Johannesson et al. 1993). For example, direct developers such as Nucella lapillus and Littorina saxatilis have been shown to vary genetically on small spatial scales (Janson \& Ward 1984, Day \& Bayne 1988). Furthermore, empirical evidence for selected local life history adaptation has been documented for several species of gastropods with low dispersal capabilities (Staiger 1957, Brown 1985, Behrens Yamada 1987, Brown \& Richardson 1992).

In contrast, for species with wide dispersal abilities, consequent gene exchange can have a homogenizing effect, which limits opportunities for genetic differentiation and character divergence among populations. Gene flow in gastropod species with planktonic dispersal (e.g. Nassarius obsoletus, Littorina scutulata) may be so pervasive as to swamp natural selection to local conditions, resulting in genetic homogeneity over large spatial scales (Scheltema 1971, Gooch et al. 1972, Stearns 1989b). For example, Behrens Yamada (1987) compared life history variation (growth, egg production) between species with direct-developing versus planktonic larvae, and showed that life history differentiation in the direct developer occurred at much shorter distances than the species with planktonic dispersal. Further, in a comparison of physiological traits between 2 gastropods with direct versus planktonic development, Parsons (1998) found that high dispersal ability was associated with increased plasticity, while restricted dispersal was associated with greater differentiation. However, some studies of species with planktonic larvae have found morphological differences among populations over relatively short distances that were presumed to have a genetic basis (Struhsaker 1968, DeWolf et al. 1998). Thus, despite some support, the existence of a relationship between dispersal ability and a genetic basis for observed trait variation among populations is far from clear.
In this study, we tested whether phenotypic variation among populations of the marine snail Cerithidea scalariformis results from environmentally driven plasticity. This snail occurs in the intertidal zone, along the banks of mangrove forests and salt marshes. Although widely distributed on both coasts of Florida, populations appear to be relatively isolated in 2 respects. First, the snail reproduces by direct development that lacks planktonic dispersal stages (Vilas \& Vilas 1970, Houbrick 1984). Second, C. scalariformis populations are often isolated among man-made impoundments, wherein habitat conditions vary considerably over short distances (less than 10 km; see 'Study site'). Here, we describe population characteristics (abundance, size structure, recruitment) for multiple C. scalariformis populations, highlighting conspicuous differences in growth and maturation of snails among some populations. To test whether environmentally driven differences in life history traits underlie the observed patterns, we conducted a reciprocal transplant experiment to measure performance (including growth, shell development [lip aperture formation], gonad maturation, and parasite prevalence) of snails from 2 source populations that were maintained under identical field conditions.

\section{MATERIALS AND METHODS}

Study site. We compared population characteristics of snails among several man-made impoundments adjacent to the Indian River Lagoon (IRL), an estuary on the east coast of central Florida, USA (Fig. 1). Built in the $1960 \mathrm{~s}$ to control mosquito populations, the impoundments are located between the IRL and the Atlantic Ocean and form a series of relatively isolated mangrove communities, dominated by a mixture of salt-tolerant plants Salicornia virginica and Batis maritima, and mangroves Avicennia germinans and Rhizophora mangle (Rey \& Kain 1989, DeFreese 1995; see also Schmalzer 1995 for a general description of this community type). More specifically, the impoundments consist of dikes (roads of 4 to $5 \mathrm{~m}$ in width), which create a physical barrier to water exchange with the IRL and among impoundments. Water exchange can occur between impoundments and the IRL through culverts, opened routinely from the late fall to spring. There are no culverts that allow water to exchange directly among impoundments.

We sampled snail populations from 5 sites along the IRL, distributed among 4 separate impoundments: Impoundments 12, 19B, 23, and 24 (Fig. 1; numbers as designated in Rey \& Kain 1989). Within Impoundment 24 , we sampled 2 different sites $(24 \mathrm{~N}$ and $24 \mathrm{~S}$, in the north and south of the impoundment, respectively), 
approximately $1 \mathrm{~km}$ apart. Impoundments varied in size, topography and management regime (see Rey \& Kain 1989). Within impoundments, snail populations were spatially heterogeneous, occupying a very small area of the impoundment. When snails were present, they were exceedingly abundant, often numbering in the tens of thousands. Selection of sampling locations was primarily based on accessibility to study sites and presence of snails.

The 5 sites could be classified into 1 of 2 general vegetation types: exposed marsh or forested marsh. Three sites (exposed marsh: Impoundments 12, 24S, and $24 \mathrm{~N}$ ) were characterized by open mudflats with sparsely scattered dead mangroves, resulting from the unusually prolonged freeze in 1989, and a few salttolerant plants and young mangroves (Rey \& Kain 1989). In contrast, the other 2 sites (forested marsh: Impoundments 23 and 19B) were dominated by similar marsh vegetation under a thick canopy of black mangroves, providing shade throughout the day.

The 2 site types differed substantially in thermal regime. Summer (July to October) water temperatures were highly variable in exposed marshes, ranging from 21 to $45^{\circ} \mathrm{C}, 21$ to $51^{\circ} \mathrm{C}$, and 22 to $40^{\circ} \mathrm{C}$ in Impoundments $12,24 \mathrm{~S}$ and $24 \mathrm{~N}$, respectively (N. F. Smith unpubl. data). In addition, exposed marshes occasionally became dry, and snails were restricted to cracks in the dried mudflats or beneath small marsh plants. By comparison, the summer water temperatures were generally cooler in forested marshes, with ranges of 17 to $45^{\circ} \mathrm{C}$ and 18 to $35^{\circ} \mathrm{C}$ in Impoundments 23 and 19B, respectively (N. F. Smith unpubl. data; see also 'Results'); here, surface sediments were never observed to become completely dry.

Reproductive biology. Cerithidea scalariformis is dioecious, females being slightly larger than males (Houbrick 1984). Females produce masses of eggs, which are laid in long strings (average length: $51 \mathrm{~mm}$ ) on the bottom sediments and plant materials, undergo direct development, and hatch as juvenile snails; hatching occurs approximately 3 wk after egg deposition. Snail populations are often parasitized by larval trematodes, with prevalence (proportion of hosts that are parasitized; Margolis et al. 1982) as high as $77 \%$ (N. F. Smith et al. unpubl. data). Trematode infections ultimately lead to permanent castration, resulting in a reduction of gonoducts and loss of all secondary sexual characteristics (e.g. ovipositor). Consequently, parasitized snails cannot be sexed, but are otherwise similar to unparasitized snails with regard to size, morphology and behavior.

Population characteristics. Density and size structure of snail populations were measured bimonthly (every other month), from October 1996 to October 1998, at each of the 5 sites: 12, 24S, 24N, 23, and 19B.

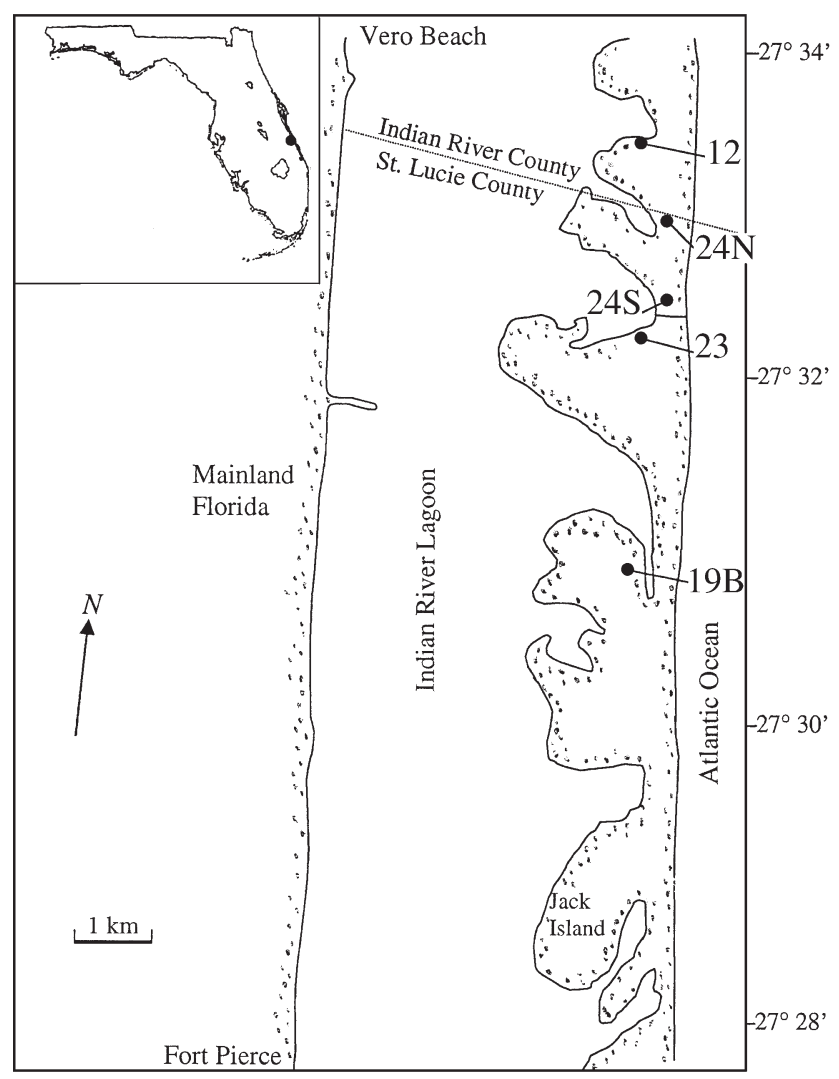

Fig. 1. Map of the mangrove marshes adjacent to the Indian River Estuary, Florida, USA. Snails were collected at Impoundments $12,24 \mathrm{~S}, 24 \mathrm{~N}, 23$, and $19 \mathrm{~B}$

Each snail population was sampled by placing a $0.25 \mathrm{~m}^{2}$ quadrat every $10 \mathrm{~m}$ along a permanent $100 \mathrm{~m}$ transect, yielding 10 quadrat samples per census. Transects were established along the vegetation (mangrove/salt marsh) fringe of the upper intertidal zone where snails were typically most common and in highest abundances (G. M. Ruiz unpubl. data). All transects therefore occurred along channels or along edges of large pools (both with standing water), consisting of similar habitat and vegetation, but differing primarily in the degree of forest canopy (see 'Study site').

For each census period and site, snails collected from the ground and vegetation of each quadrat were counted to estimate density, were measured (maximum length) to the nearest $0.1 \mathrm{~mm}$, and were classified as mature or immature based upon shell characteristics. Cerithidea scalariformis develops a thickened outer lip at the shell aperture upon reaching sexual maturity (see Houbrick 1984, Vermeij 1993). Snails with thin and fragile apertures, lacking conspicuous thickness, were classified as immature. Thus, we used this shell characteristic to estimate maturity over time 
to avoid destructive sampling (i.e. dissections), while recognizing that parasitism may (although rarely) affect aperture development (authors' pers. obs.). When quadrat densities exceeded 100 snails, at least 50 snails were randomly subsampled to measure size and maturity; otherwise, all snails were measured.

Population characteristics were compared among all 5 sites. For each collection date and site, mean density was estimated for all snails (mature and immature) to highlight the relative contribution of immature snails (or recruitment) among populations. Mean densities and coefficients of variation were compared (with 1factor NOVA) among all 5 sites, using data across all dates. The mean size of mature and immature snails was also estimated for each site and date; in addition, mean sizes across all dates were compared among 5 sites for mature and immature snails (using 1-factor ANOVA).

With the same census data, a more detailed comparison was made between populations in Impoundments 24S-Exposed and 23-Forested, highlighting the dynamics and life history patterns of populations that were exposed to extremes in habitat characteristics and that displayed some of the largest differences in many population characters (see 'Results'); these 2 populations were used for the reciprocal transplant experiment (see following subsection). For each population, we estimated the percentage of mature and immature snails, dividing individuals into $1.0 \mathrm{~mm}$ size classes for each bimonthly census from April to October in each year.

Reciprocal transplant experiment. To test whether environmental conditions contributed to the observed variation in characteristics among snail populations, we conducted a reciprocal transplant experiment between an exposed (Impoundment 24S) and a forested (Impoundment 23) marsh. Juveniles from each population were raised together within each impoundment. We predicted that if no differences remained between the 2 populations raised in the same habitat, this would fail to reject our hypothesis that phenotypic response to different environmental cues was sufficient to explain the variation in population traits. However, if differences persisted between snail populations, then further studies would be necessary to partition the relative contribution of genetic effects, maternal effects, and environmental cues to life history patterns. Hence, this experiment represented the first step to understanding whether environmental conditions (not genetic differences) influence life history, shell morphology and parasitism of Cerithidea scalariformis.

The snail populations selected for this experiment exhibited extreme differences in population characteristics (see 'Results') and were exposed to the most extreme differences in canopy cover. They were also the populations in closest proximity to each other, with approximately $200 \mathrm{~m}$ between them. Impoundment $24 \mathrm{~S}$ is an exposed mudflat with approximately $25 \%$ vegetative cover (Rey \& Kain 1989). This site experienced relatively high water temperature and salinity (see 'Results'). In contrast, Impoundment 23 has substantial vegetative overgrowth, consisting of a thick canopy of old, live mangroves along a shallow creek bed that provides nearly $100 \%$ of the population with shade. Water temperature and salinity were lower and more stable at this impoundment (see 'Results'). For each experimental site, minimum and maximum water temperature $\left({ }^{\circ} \mathrm{C}\right)$ measurements were recorded biweekly over a $48 \mathrm{~h}$ period between 13 May and 15 September 1997, using a permanently stationed minimum/maximum thermometer near each experimental set-up. Additionally, salinity (ppt) measurements were taken biweekly at Impoundments $24 \mathrm{~S}$ and 23 between 13:00 and 14:00 h.

For the experiment, we collected 250 snails within the size range 11.0 to $14.9 \mathrm{~mm}$ on 1 April 1997, over an area of $10 \mathrm{~m}^{2}$ from each of the 2 impoundments. The growth of these juvenile snails to the adult size range of 18.0 to $25.0 \mathrm{~mm}$ was expected over the course of the study. Snails were marked with acrylic paint on the shell apex, color-coded according to their habitat source. Four days following collection, 125 snails from each site were returned to their original site as controls and 125 were transplanted into the other site, as described below.

Snails were distributed among 5 enclosures (surface area $0.25 \mathrm{~m}^{2}$ ) at each site, allowing recapture of snails to make repeated measurements of snail size and maturity (based on the development of an aperture). At the beginning of the experiment, all collected snails were individually measured and randomly assigned to either a control or transplanted group. The mean snail size of the 4 treatment groups was $12.18 \mathrm{~mm} \pm 0.09 \mathrm{SE}$ (exposed to exposed), $12.10 \mathrm{~mm} \pm 0.09 \mathrm{SE}$ (forested to exposed), $12.44 \mathrm{~mm} \pm 0.10 \mathrm{SE}$ (forested to forested), and $12.05 \mathrm{~mm} \pm 0.10 \mathrm{SE}$ (exposed to forested). There were no significant differences among the initial snail sizes of the 4 treatment groups (ANOVA; df $=3,496$, $F=1.98, \mathrm{p}>0.05)$. Both control and transplanted snails were added to every enclosure, giving a total of 50 snails in each (25 control, 25 transplanted). Enclosures consisted of $4 \mathrm{~mm}$ Vexar nylon mesh walls, which were buried to a depth of $10 \mathrm{~cm}$ and rose to a height of $0.50 \mathrm{~m}$, allowing snails full access to bottom sediments and preventing them from escaping. The top edges of the enclosure walls were folded inward towards the enclosure walls, so that the mesh would not completely shade the interior (allowing diatom growth and preventing snails from crawling out of the enclosure). 
Snails were measured bimonthly (every $2 \mathrm{wk}$ ) to the nearest $0.1 \mathrm{~mm}$ and examined for the presence or absence of a thickened aperture. Missing snails were replaced with local snails of similar size to maintain snail density within enclosures, although these were not marked as above. Replacement snails were not used for any subsequent measurements or analyses. In early September, many snails transplanted to the exposed marsh began to die (as senescence occurs in early fall for this population), which forced us to terminate the experiment. On 15 September 1997, snails from each of the 5 enclosures at each site were removed, and 30 snails from each treatment were selected randomly for dissection to determine gonad maturation and parasitism. Males with sperm in the vas deferens were considered sexually mature, as were females with ovaries containing eggs. Parasitized snails were identified by examining the gonad and mantle for larval trematodes (see Holliman 1961, McNeff 1978). These parasites reproduce asexually within the snails and ultimately castrate the snail host (see Kuris 1974).

Treatment groups were compared to test whether snails from the 2 source populations differed in their maturation, growth, shell morphology, and parasitism rates when exposed to identical environmental conditions. Two-way ANOVA was used to test the effect of origin (source) and destination (transplant site) on sexual maturation for male and female snails. Snails parasitized by larval trematodes (see Holliman 1961, McNeff 1978) were separated from the gonad maturation analyses at the end of the experiment, as these parasites block reproduction of their snail hosts (Kuris 1974). Similarly, a 2-way ANOVA was used to test the effect of origin (source) and destination (transplant site) on final shell size and shell aperture development. The proportion of snails with thickened apertures in each enclosure was arcsine-transformed prior to the ANOVA. Parasitism data did not meet the assumptions of parametric tests (e.g. normality, homogeneity of variance), and thus, Wilcoxon signed rank tests were used to test for significant differences in parasitism between habitats and between transplanted snails and those remaining in source habitats.

\section{RESULTS}

\section{Density}

Mean density differed significantly among the 5 snail populations, both for all snails (ANOVA, $\mathrm{df}=4$, $F=9.53, \mathrm{p}<0.0001$ ) and for immature snails (ANOVA, $\mathrm{df}=4, F=8.46, \mathrm{p}<0.0001$; Fig. 2). Multiple comparison of means indicated that the mean density of snails (all snails and immature snails) was significantly higher in Impoundment 24S than in Impoundments 12, 24N, 23, and 19B, but the mean densities of these latter snail populations were not significantly different from each other (Table 1).

Overall, 2 types of temporal density patterns were apparent among populations, corresponding to whether sites were exposed or forested. Populations in exposed marshes (Impoundments 12, 24S, and 24N) exhibited relatively high mean densities and large temporal fluctuations (Fig. 2A). Mean total (mature + immature) snail densities ranged between 37.0 and 179.5 snails per $0.25 \mathrm{~m}^{2}$, and the coefficient of variation for density was 0.85 to 1.87 (Table 1). In contrast, snail populations in forested marshes (Impoundments 23 and 19B) had relatively low and stable mean densities, exhibiting mean total densities of 11.7 to 15.6 snails per $0.25 \mathrm{~m}^{2}$ and coefficients of variation for density between 0.27 and 0.45 (Table 1).

Density patterns among impoundments were influenced primarily by the density of immature snails. Immature snails exhibited relatively high densities, as well as coefficients of variation for density, for populations in exposed versus forested sites (Table 1). Moreover, overall density patterns (for mature + immature snails) were dominated by variation in the density of immature snails (Fig. 2A). In exposed marshes, snail densities sometimes increased manyfold in October and December, reflecting recruitment of a new cohort (see 'Size distribution'). Although recruitment also occurred in forested marshes, densities of immature snails were lower and relatively stable in those populations.

\section{Size distribution}

The mean size of both mature and immature snails differed significantly among the 5 populations (mature snails: ANOVA, df $=4, F=907.20, \mathrm{p}<0.0001$; immature snails: ANOVA, df $=4, F=16.44, \mathrm{p}<0.0001$; Fig. 2B and Table 1). Pairwise comparison of means indicated that mature snails in Impoundment 23 were significantly larger than those from all other sites (Table 1). A similar comparison for immature snails found mean size was significantly greater for the forested populations (Impoundments 23 and 19B) compared to the exposed populations (Impoundments 12, 24S, and 24; see Table 1).

The mean size of mature snails at all sites was relatively stable within populations, but that of immature snails varied over time (Fig. 2B). For each population, the smallest mean size occurred in October and December, followed by an increase from February to August. Further, the rapid increase in immature snail density from August to October in the exposed 


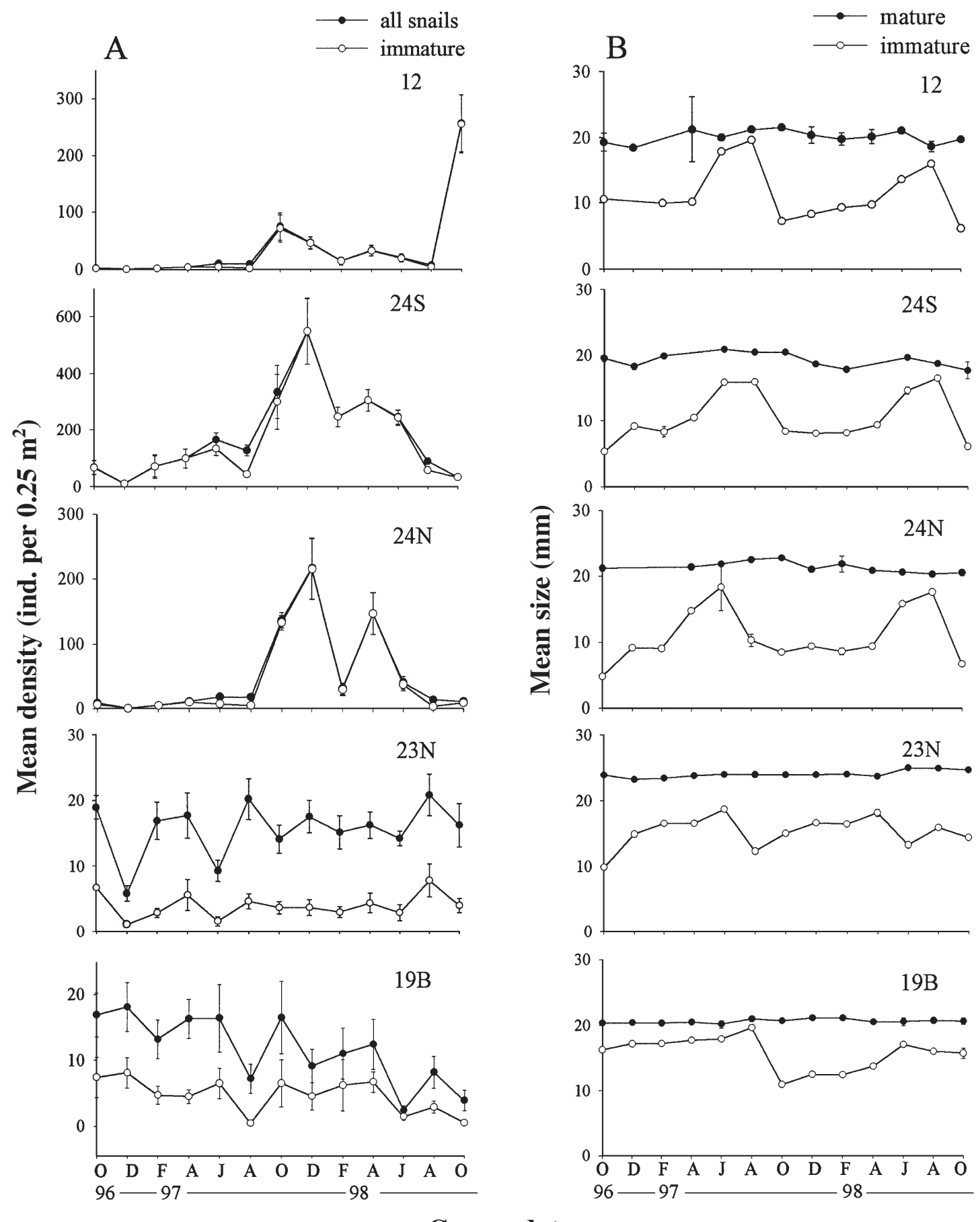

Census dates

Fig. 2. Cerithidea scalariformis. (A) Mean density $( \pm \mathrm{SE})$ of all and immature snails sampled during the bimonthly surveys from each of the 5 sites. (B) Mean size $( \pm \mathrm{SE})$ of mature and immature snails from each of the 5 sites sampled bimonthly from October 1996 to October 1998

marshes corresponded to a decrease in mean size (Fig. 2A). This decline in mean size between August and October is due to both the recruitment of a new cohort (or an increased number of small individuals) and maturation of the previous cohort.
Despite some general seasonal patterns, the temporal changes in size structure differed strongly among populations, underscoring differences in recruitment, growth, and survivorship. Fig. 3 illustrates some of these differences for Impoundments 23 and $24 \mathrm{~S}$, a 
Table 1. Cerithidea scalariformis. Mean density and size $( \pm$ SE) of snails censused bimonthly from October 1996 to October 1998 from 5 sites (Impoundments 12, 24S, and 24N are exposed sites; Impoundments 23 and 19B are forested sites). CV represents the coefficient of variation. Multiple comparison of means was analyzed by Tukey's Studentized Range test. Means with the same letter are not significantly different from each other $(\alpha=0.05)$

\begin{tabular}{|c|c|c|c|c|c|}
\hline & 12 & $24 \mathrm{~S}$ & $24 \mathrm{~N}$ & 23 & $19 \mathrm{~B}$ \\
\hline \multicolumn{6}{|c|}{ Density (ind. per $0.25 \mathrm{~m}^{2}$ ) } \\
\hline All snails & $37.01 \pm 19.23$ & $179.47 \pm 42.13$ & $50.38 \pm 19.22$ & $15.61 \pm 1.16$ & $11.66 \pm 5.20$ \\
\hline $\mathrm{CV}$ & 1.87 & 0.85 & 1.38 & 0.27 & 0.45 \\
\hline Tukey grouping & $\mathrm{B}$ & A & $\mathrm{B}$ & $\mathrm{B}$ & $\mathrm{B}$ \\
\hline Immature & $34.85 \pm 19.25$ & $165.07 \pm 43.08$ & $46.48 \pm 19.55$ & $3.93 \pm 0.53$ & $4.64 \pm 0.72$ \\
\hline $\mathrm{CV}$ & 1.99 & 0.94 & 1.52 & 0.49 & 0.56 \\
\hline Tukey grouping & $\mathrm{B}$ & A & B & $\mathrm{B}$ & $\mathrm{B}$ \\
\hline \multicolumn{6}{|c|}{ Size $(\mathrm{mm})$ (ind. per $0.25 \mathrm{~m}^{2}$ ) } \\
\hline Mature & $20.53 \pm 0.29$ & $20.17 \pm 0.33$ & $21.56 \pm 0.24$ & $24.01 \pm 0.14$ & $20.50 \pm 0.08$ \\
\hline Tukey grouping & $\mathrm{C}$ & $\mathrm{C}$ & $\mathrm{B}$ & $\mathrm{A}$ & $\mathrm{C}$ \\
\hline Immature & $9.83 \pm 1.23$ & $11.23 \pm 1.09$ & $10.20 \pm 1.19$ & $14.85 \pm 0.67$ & $15.02 \pm 0.71$ \\
\hline Tukey grouping & $\mathrm{B}$ & $\mathrm{B}$ & B & A & $\mathrm{A}$ \\
\hline
\end{tabular}

Impoundment 23N
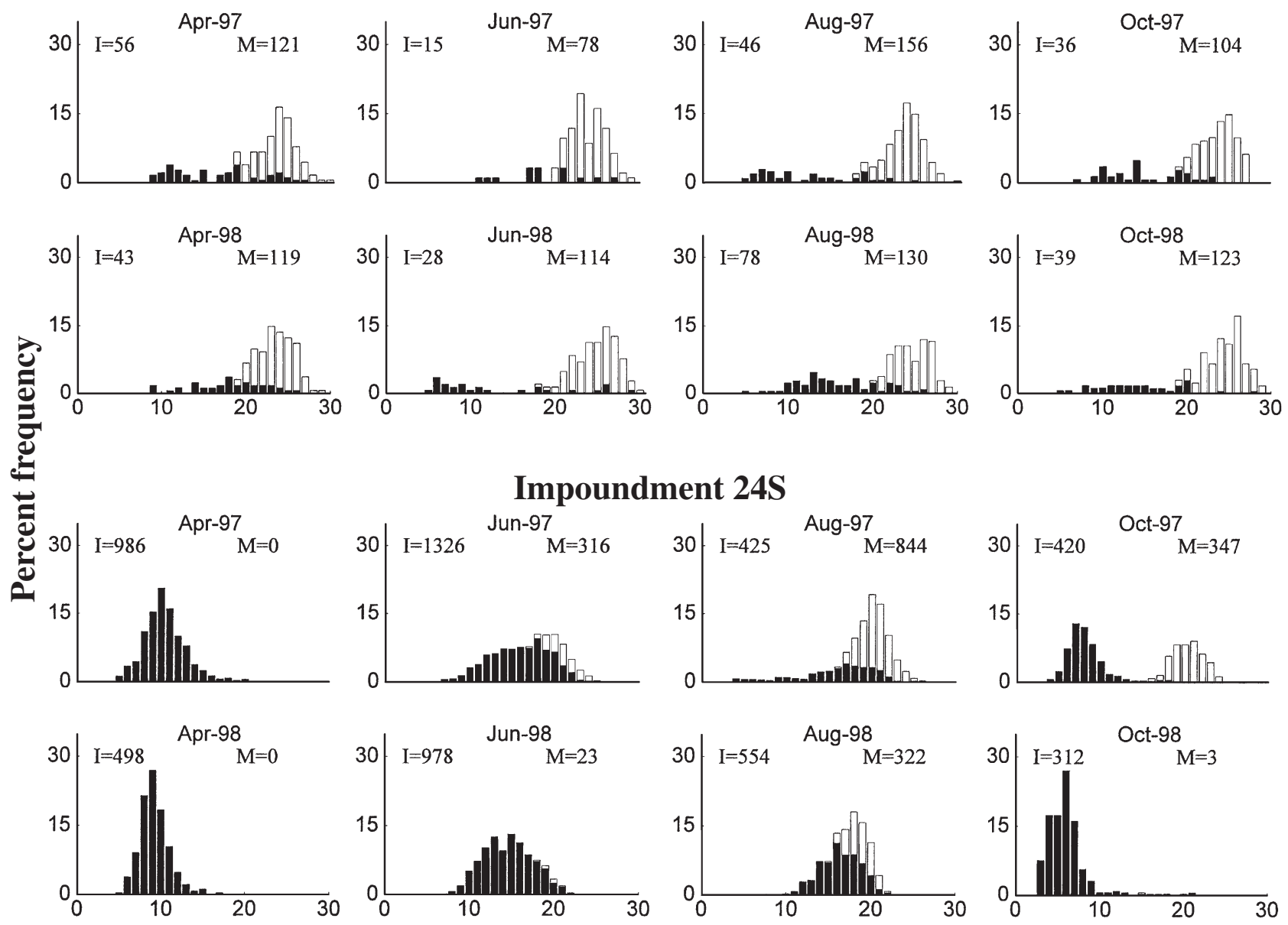

Shell length $(\mathbf{m m})$

Fig. 3. Cerithidea scalariformis. Size frequency distributions of mature (open bars) and immature (black bars) snails sampled in April, June, August and October 1997 and 1998 in Impoundments 23 and 24S. I and M represent the total number of immature and mature snails, respectively 

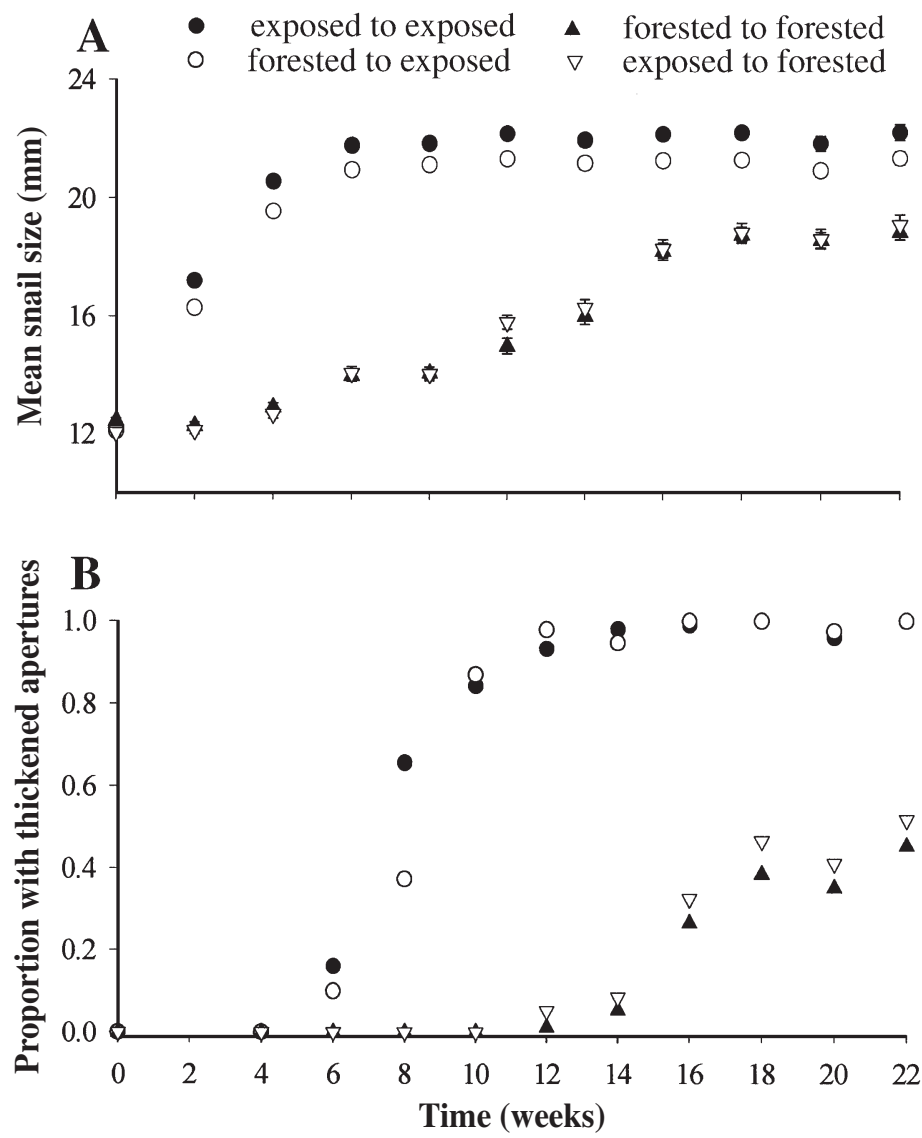

Fig. 4. Cerithidea scalariformis. (A) Mean snail size $( \pm$ SE) over time for each of the 4 treatments in the reciprocal transplant experiment.

(B) Proportion of snails with thickened shell apertures for each of the 4 treatments

forested and exposed marsh, respectively. Beyond variation in the magnitude of recruitment (as described above), the size distribution of immature snails exhibited stronger modes in Impoundment 24S than in 23, suggesting recruitment was more synchronous. In fact, we observed the presence of small snails and egg strands throughout the year in Impoundment 23-Forested, and no evidence of year-round reproduction was found in the other site. Most striking, however, was the apparent difference in longevity of mature snails between sites: mature snails were completely absent from Impoundment 24S-Exposed by the April census in both years, but were always present and dominated the population in Impoundment 23-Forested. This difference resulted from the relatively high fall mortality (causing complete replacement) in Impoundment 24S-Exposed that is absent from the other population, where snails may live for multiple years. As evident in Fig. 3, this mortality can occur after August (1998) or October (1997).

Thus, although the populations in Impoundments 23-Forested and 24S-Exposed were separated by the shortest distance of any 2 populations, they exhibited some of the most extreme differences in size, recruitment, and adult survivorship among the populations studied. We therefore selected these populations for use in the reciprocal transplant experiment, testing the effect of environment on variation in life history characteristics.

\section{Reciprocal transplant experiment}

Shell size and growth

Snails from the 2 source populations experienced similar growth patterns when maintained in the same habitat, but growth patterns were significantly different between habitats (Fig. 4A). More specifically, snails maintained in the exposed marsh experienced higher growth rates than snails maintained in the forested marsh. Destination (transplant site), not origin (source), had a significant effect on final shell size (Table 2).

\section{Shell development}

The development of thickened shell apertures varied over time, with a higher proportion of snails developing them in the exposed marsh than in the forested marsh (Fig. 4B). In both sites, the proportion of transplanted snails that developed a thickened shell aperture matched that of the ambient population (Fig. 4B). Like final shell size, destination, not source, had a significant affect on aperture development (Table 2).

Table 2. Results of 2-way ANOVAs on the effects of origin (source) and destination (transplanted site) on final shell size and shell aperture development at the end of the transplant experiment

\begin{tabular}{|lrrrr|}
\hline Source of variation & df & SS & \multicolumn{1}{c|}{$F$} & \multicolumn{1}{c|}{$p$} \\
\hline Final shell size & & & & \\
Origin & 1 & 1.12 & 0.78 & 0.389 \\
Destination & 1 & 41.47 & 28.96 & $<0.001$ \\
Origin $\times$ Destination & 1 & 1.07 & 0.75 & 0.401 \\
Error & 16 & 22.91 & & \\
& & & & \\
Shell aperture & & & & \\
Origin & 1 & 0.07 & 3.04 & 0.101 \\
Destination & 1 & 3.01 & 134.05 & $<0.001$ \\
Origin $\times$ Destination & 1 & 0.00 & 0.13 & 0.724 \\
Error & 16 & 0.36 & & \\
\hline
\end{tabular}



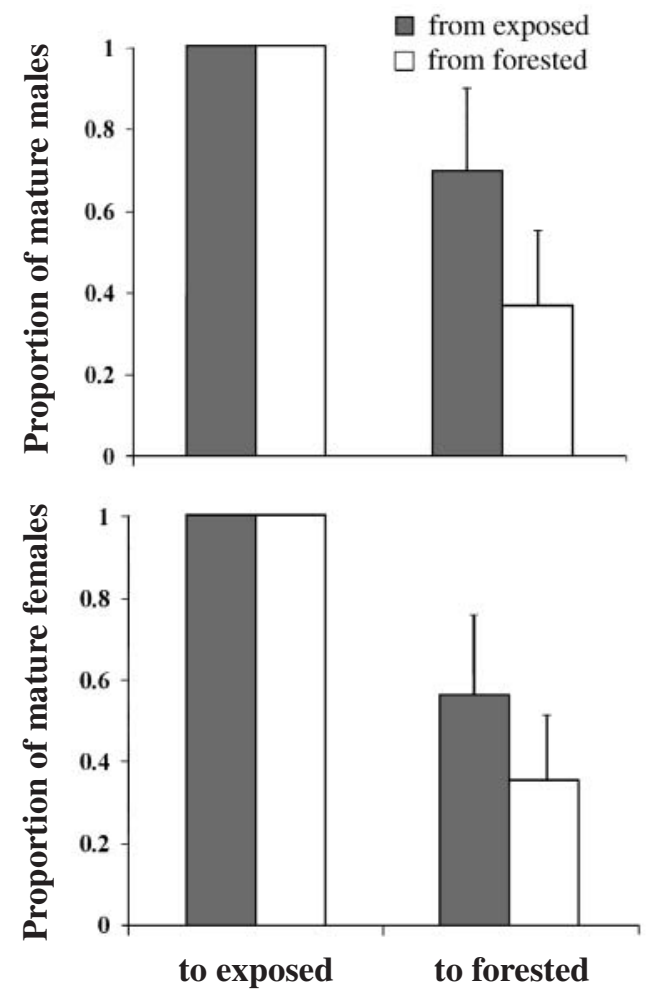

Fig. 5. Cerithidea scalariformis. Proportion of male and female snails that developed to sexual maturity for each of the 4 experimental treatments. Error bars are SE

\section{Sexual maturation}

For both males and females, a significantly greater proportion of snails reached sexual maturity in the exposed marsh than in the forested marsh (Fig. 5, Table 3). However, as above, there was no significant

Table 3. Results of 2-way ANOVAs on the effects of origin (source) and destination (transplanted site) on sexual maturation of males and females based on gonad assays. Parasitized snails were excluded from the analysis

\begin{tabular}{|lrrrr|}
\hline Source of variation & df & SS & $F$ & $p$ \\
\hline Males & & & & \\
Origin & 1 & 0.10 & 0.50 & 0.491 \\
Destination & 1 & 1.28 & 6.54 & 0.024 \\
Origin $\times$ Destination & 1 & 0.04 & 0.19 & 0.670 \\
Error & 13 & 2.56 & & \\
& & & & \\
Females & & & & \\
Origin & 1 & 0.02 & 0.17 & 0.684 \\
Destination & 1 & 4.88 & 39.60 & $<0.001$ \\
Origin $\times$ Destination & 1 & 0.13 & 1.08 & 0.317 \\
Error & 14 & 1.73 & & \\
\hline
\end{tabular}

effect of origin (or source) on sexual maturation, and snails maintained within the same habitat experienced similar patterns of gonad maturation (Fig. 5). Further, the mean size of mature snails was also significantly different among treatments (ANOVA, $\mathrm{df}=3, F=7.70$, $\mathrm{p}<0.005$; Fig. 6), being larger in the exposed marsh than in the forested marsh (Fig. 6).

\section{Parasitism}

Snails originating from and maintained in the exposed marsh experienced significantly higher infection rates than those originating from the same population, but maintained in the forested marsh (Wilcoxon signed rank test, $\mathrm{p}<0.05$; Fig. 7). Likewise, snails originating from the forested marsh experienced significantly higher parasitism rates when maintained in the exposed marsh than those maintained in the forested marsh (Wilcoxon signed rank test, p < 0.05). Within sites, there was a significant difference in parasitism between the 2 source groups maintained within the forested marsh (Wilcoxon signed rank test, $\mathrm{p}<0.05$ ), but not in the exposed marsh ( $p>0.05)$.

All parasitized snails exhibited a thickened aperture and were completely castrated, as there was no sign of sperm or eggs in their gonad. Further, gonad tissue was replaced by trematode larvae (e.g. sporocysts,

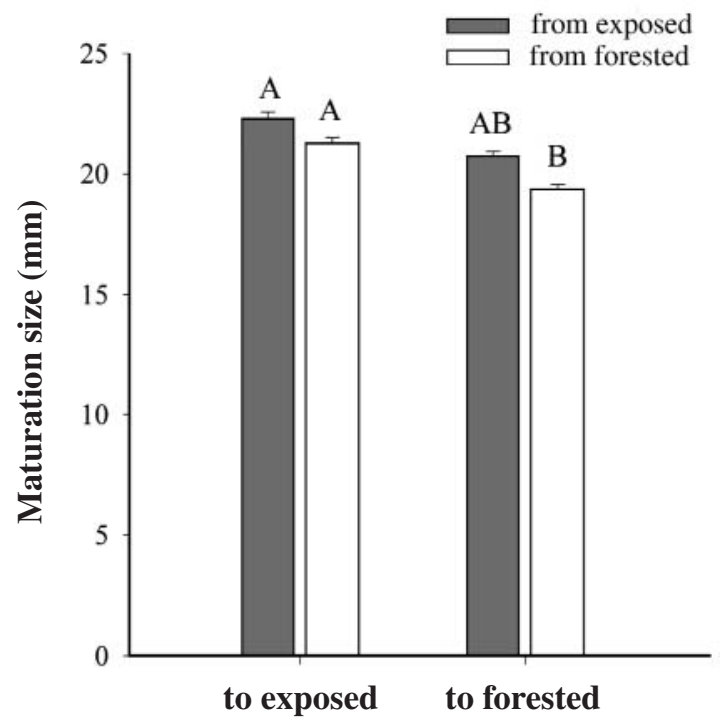

Fig. 6. Cerithidea scalariformis. Mean snail maturation size $(+\mathrm{SE})$ for each of the experimental treatments from the last census of the reciprocal transplant experiment. Multiple comparison of mean maturation sizes was analyzed by a Tukey's Studentized Range test. Means with the same letter are not significantly different from each other 


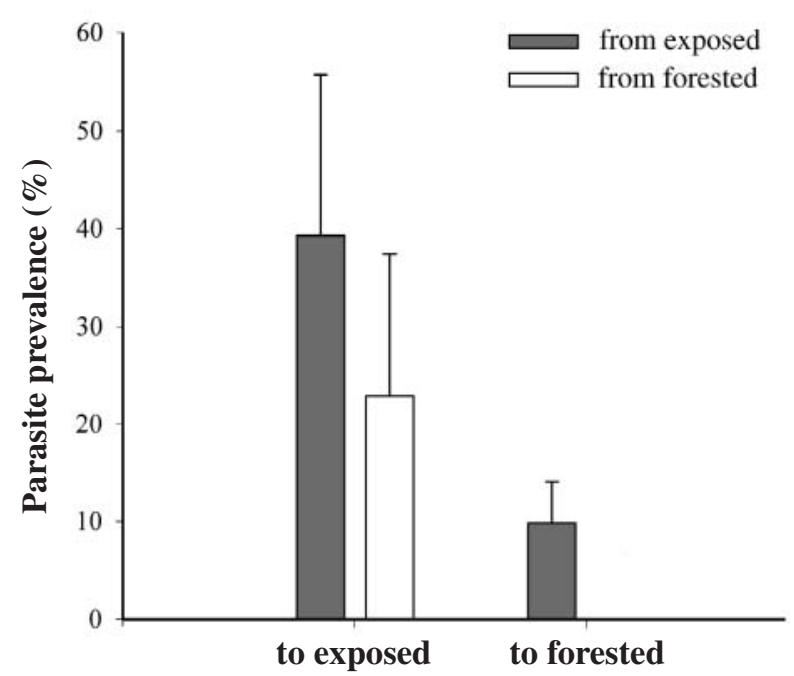

Fig. 7. Cerithidea scalariformis. Prevalence $(\%+\mathrm{SE})$ of parasitic trematodes for each experimental group in the reciprocal transplant experiment

rediae) and the ovipositor in all infected females was greatly reduced in size compared to those in uninfected females. There was no significant difference between final shell size of parasitized and non-parasitized snails for all treatment groups (Student's $t$-test, $\mathrm{p}>0.05)$.

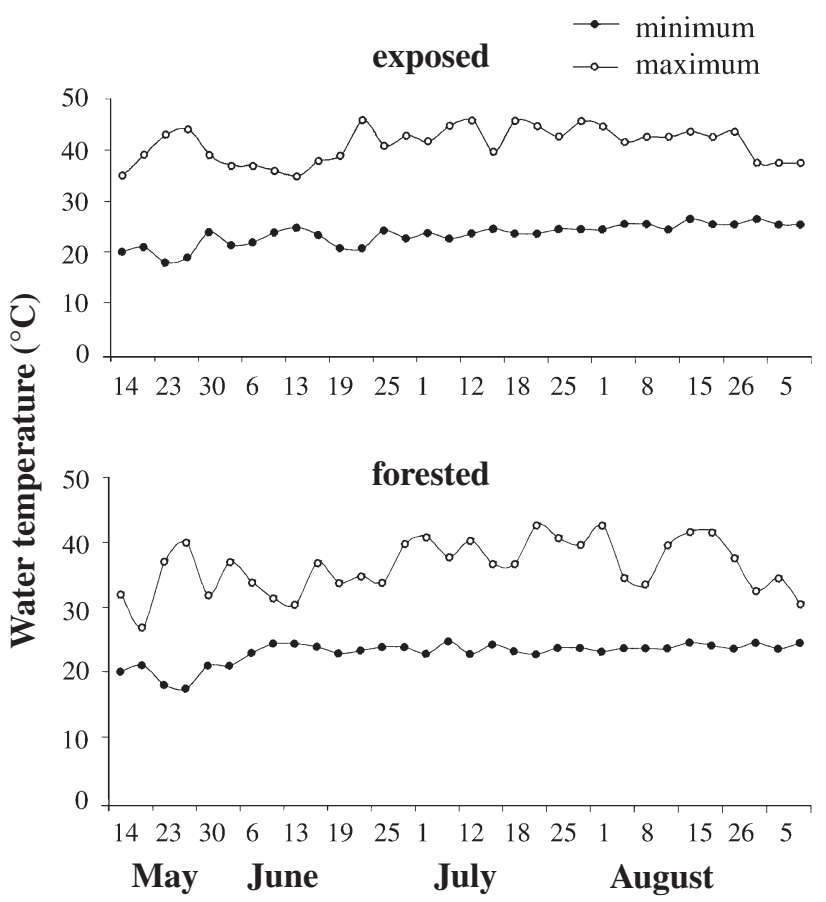

Fig. 8. Minimum and maximum water temperatures $\left({ }^{\circ} \mathrm{C}\right)$ from the exposed (Impoundment 24S) and forested (Impoundment 23) sites
Temperature and salinity

Water temperatures ranged from 17 to $43^{\circ} \mathrm{C}$ and 18 to $46^{\circ} \mathrm{C}$ for the forested and exposed marsh, respectively. Comparison of water temperature data showed that the forested marsh experienced significantly lower minimum water temperatures than did the exposed marsh (mean forested $=23.2^{\circ} \mathrm{C}$, mean exposed $=24^{\circ} \mathrm{C}$; paired $t$-test, df $=33, \mathrm{p}<0.005$; Fig. 8), whereas the exposed marsh had significantly higher maximum water temperatures than did the forested site (mean forested $=36.4^{\circ} \mathrm{C}$, mean exposed $=41.3^{\circ} \mathrm{C} ;$ paired $t$-test, df $=33$, p $<0.0001$; Fig. 8).

Both sites experienced large salinity fluctuations (forested: 6 to $35 \mathrm{ppt}$, exposed: 5.5 to $45 \mathrm{ppt}$ ). However, salinity was significantly higher in the exposed marsh than in the forested marsh (mean forested $=22.6 \mathrm{ppt}$, mean exposed $=26.6 \mathrm{ppt}_{\text {; }}$ paired $t$-test, $\mathrm{df}=42, \mathrm{p}<$ 0.0001; Fig. 9).

\section{DISCUSSION}

\section{Variation among field populations}

Habitat type was associated with many differences in the life history and demography of Cerithidea scalariformis. Large differences in the temporal dynamics of snail density among sites resulted primarily from habitat-related differences in recruitment dynamics (Fig. 2). In exposed marsh sites (i.e. 24S, 24N, and 12), recruitment occurred as a strong seasonal pulse, consisting of relatively high densities of small snails in the late summer and fall, followed by few new recruits in the spring and summer. In contrast, recruitment in forested sites (i.e. 23, 19B) occurred in relatively low densities throughout the year.

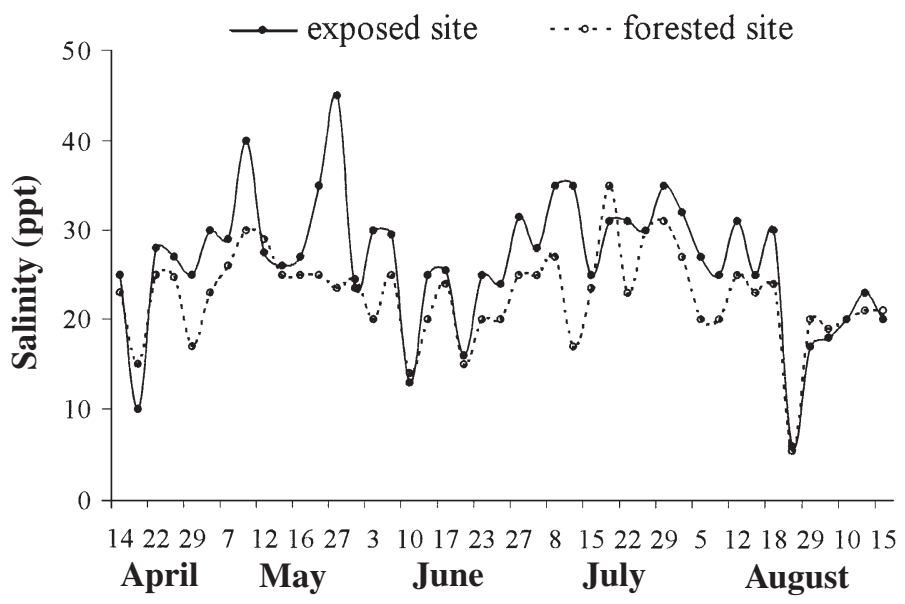

Fig. 9. Water salinity (ppt) from the exposed (Impoundment 24S) and forested (Impoundment 23) sites 
Recruitment patterns contributed to the relative stability of snail populations between habitat type, as they can influence both the size structure and dynamics of gastropods (Sutherland 1970, Lewis \& Bowman 1975, Fletcher 1984), but mortality patterns were also strikingly different between habitats. At exposed marsh sites, large recruitment events in summer and fall were followed by high mortality (decline in densities) of immature snails during winter and spring, and most mature snails died in late summer and fall (Fig. 2). In contrast, immature and mature snails were present in similar abundances among seasons in the forested sites, indicating a very different survivorship pattern than that observed in the exposed marsh habitat. The presence of mature snails during the winter strongly suggests that these snails live for more than $1 \mathrm{yr}$. Thus, continuous recruitment throughout the year, combined with lower mortality rates, resulted in greater stability (i.e. low coefficient of variation) for snail density in forested sites compared to exposed marsh sites.

Differences in recruitment and mortality, and hence dynamics, among Cerithidea scalariformis populations corresponded to the range and variation of environmental conditions among sites. For example, sites with pulsed snail recruitment and short $(<1 \mathrm{yr})$ survivorship consisted of extensive mudflats with low vegetative cover (Rey \& Kain 1989). These habitats underwent the largest changes in water temperature and salinity. In contrast, sites with long-lived snails and continuous recruitment were sheltered, dense mangrove forests. Temperature and salinity at these localities did not fluctuate as widely as at the exposed mudflat sites.

Although closest in proximity, snail populations in Impoundments 24S-Exposed and 23-Forested exhibited some of the greatest differences in the size of mature snails, magnitude of recruitment, and longevity of mature and immature snails. Furthermore, the rapid shift in size distribution of immature snails in Impoundment 24S-Exposed suggests a much faster growth rate than that observed in Impoundment 23-Forested (Fig. 3). These sites also exhibited some of the greatest differences in physical conditions. More specifically, Impoundment 23-Forested had the densest canopy of mangrove forest among all sites, resulting in nearly continuous shade and reduced temperature extremes (Fig. 8).

\section{Phenotypic plasticity}

Results of the reciprocal transplant experiment show that site, and not source population, was responsible for differences in the growth and maturation rates between Impoundments 24S-Exposed and 23-Forested. Snails maintained in the exposed marsh exhibited faster growth, developed a thickened shell aperture earlier, and attained sexual maturity earlier than did snails maintained in the forested marsh. Snails transplanted to a different environment performed as well as the snail population from that habitat. Additionally, we have observed striking differences in the lifespan of snail populations; snails occurring in exposed marshes (e.g. 24S, $24 \mathrm{~N}$, and 12) exhibited a predictable and distinct annual life history whereas snails in forested marshes (e.g. 23 and 19B) exhibit a longer and less well-defined lifespan.

Our data indicate that variation in life history characteristics among Cerithidea scalariformis populations (and habitats) results from plasticity to local environmental conditions, in contrast to previous findings that species with limited dispersal often exhibit low levels of phenotypic plasticity (Janson 1982, Behrens Yamada 1987, Johannesson et al. 1993). Thus, although environmental (including biotic) factors can constrain life history or induce phenotypic shifts in life history parameters (e.g. lifespan, growth, maturation rate), our censuses and transplant experiment show that $C$. scalariformis is able to shift its life history with current environmental conditions.

In addition to differences in rates of growth, size, and maturation, snails transplanted into the exposed marsh also experienced a greater prevalence of trematode parasitism than those exposed experimentally to the forested site, regardless of source. Over the past $10 \mathrm{yr}$, our long-term data show that the prevalence of parasitism of mature snails from field collections is similar in Impoundments 24S-Exposed and 23-Forested, ranging typically from 20 to $30 \%$ in early fall (N. F. Smith et al. unpubl. data). Given that the snails grow at different rates and experience different survivorship between these sites (Figs. $2 \& 3$ ), the rate of parasite accumulation appears to be consistently different between the 2 populations, as observed in the transplant experiment. Thus, snails in Impoundment 24S-Exposed were shorter-lived and accumulated parasites at a much faster rate than those in Impoundment 23Forested, where exposure to parasites over a longer time period (longevity) appeared to compensate for the low rate of accumulation and resulted in a parasite prevalence for mature snails that was roughly similar in both sites (e.g. see Rothschild 1941, Curtis \& Hurd 1983 for discussion of age- and size-related increases in parasitism).

\section{Mechanisms, cues, and hypotheses}

A plastic life history may allow an organism to respond to, and persist across, a wide spectrum of environmental conditions. More specifically, spatial or 
temporal changes in habitat conditions may favor phenotypes that can respond to these environmental conditions (Bradshaw 1965, Lively 1986a, Schlichting 1986, Trussell 1997; see review by Tollrian \& Harvell 1999). For example, Brown (1985) found population differences in growth and size at maturation between snails reared in vernal and permanent ponds, and suggested that phenotypic plasticity is an adaptive response to inhabiting such an unpredictable environment as vernal pools.

A variety of biological and environmental factors that vary in space or time can play an important role in the evolution and expression of life history characteristics. In the case of Cerithidea scalariformis, conspicuous environmental differences existed among sites, including temperature regime, salinity, and shading. These may have had direct effects on the snails' demographic performance. Biological features may co-vary with habitat type, possibly in response to environmental differences. For example, life history differences among snail populations may result from differences in quality or quantity of food resources, which may well vary as a function of temperature and light conditions. Indeed, several species of gastropods have been shown to exhibit faster growth when water temperatures are relatively warm (Largen 1967, Phillips et al. 1973, Janson 1982). Increased water temperatures may stimulate metabolic rates, leading to faster growth (Parry 1978, Clarke 1987). Further, high temperatures can also decrease longevity (Medvedev 1990) and the time required to attain maturity. Clarke (1987) suggested that at higher latitudes, organisms tend to have slower growth rates, longer lifespan and lower basal respiration rates.

Food availability or quality could also account for differences in life history patterns (Spight 1973, Kautsky 1982, MacDonald \& Thompson 1985). We suggest that increased food resources, in response to higher temperatures, may explain why snails in Impoundment 24S-Exposed grow faster, reach maturity earlier, and have a shorter lifespan than snails in the forested site. Higher temperatures in the exposed marsh may lead to higher abundance or quality of food, possibly contributing to faster growth rates than those observed in forested sites. However, we do not have data on the abundance or quality of food resources (benthic diatoms) at these sites to test this hypothesis.

Although we have not yet tested for the proximate mechanism for varied snail performance among sites, parasitism may also be an important factor explaining observed life history differences between the 2 populations of Cerithidea scalariformis. In the congener $C$. californica, Lafferty (1993) found a negative association between maturation size and parasite prevalence, suggesting that earlier maturation may be an adapta- tion to a high risk of parasitic castration. By adjusting age at maturity or age-specific fecundity, hosts can increase the likelihood of successful reproduction before becoming infected with a parasitic castrator (Minchella 1985, Thornhill et al. 1986, Ruiz \& Lindberg 1989, Ruiz 1991, Forbes 1993). Since delayed reproduction can increase the risk of parasitism, and parasitism can exceed $30 \%$ prevalence in C. scalariformis, phenotypic plasticity for early reproduction in the presence of parasites may minimize the fitness cost of parasitic castrators. Further, earlier age of reproduction is often associated with reduced life span (Stearns 1976, 1992, Reznick et al. 1990, Taylor \& Gabriel 1992), such that a shift in reproductive schedule may influence a suite of other life history traits.

The observed differences in life history among populations may lie in habitat-specific or site-specific differences in parasitism risk. At Impoundment 24SExposed, parasitism risk was significantly greater than at Impoundment 23-Forested. Although many factors may contribute to this result, bird use was substantially different between these 2 particular sites. We regularly encountered several species of wading birds (white ibis, roseate spoonbill, woodstork, tricolored heron, and snowy egret) at Impoundment 24S-Exposed. In contrast, only on rare occasions did we encounter any birds at our site in Impoundment 23-Forested. Since birds are definitive hosts for many trematodes that infect snails, and thus a source of parasitic infection for Cerithidea scalariformis, this may contribute to the higher risk of parasitism at the exposed site. Furthermore, Smith (2001) demonstrated that proximity to bird perching sites significantly increased parasitism rates for C. scalariformis at a different site in the same region.

Although this study demonstrates phenotypic plasticity for rates of growth and maturation, it was not designed to test for underlying causes and associated evolutionary trade-offs. We hypothesize that the increased growth rate and earlier age of maturity in exposed marsh (versus forested habitat) may be a response to variation in food resources and/or an increased risk of parasitism. Thus, the proximate cues and mechanisms (e.g. variation in food resources, temperature, parasitism) that elicit shifts in growth and maturity, and possibly other life history traits that differed among sites (e.g. longevity, size, reproductive schedule), remain unclear. A growing body of literature underscores the significance of phenotypic plasticity as an evolutionary strategy (e.g. Bradshaw 1965, Brown 1985, Lively 1986a,b, Schlichting 1986, Stearns 1989a, Tollrian 1995, Trussell 1997; see review by Tollrian \& Harvell 1999). Historically, the role of parasites in host populations has been a central focus of parasitology research, focusing on host population dynam- 
ics (e.g. Anderson 1978, Anderson \& May 1978, Blower \& Roughgarden 1987, Hudson et al. 1992), and more recently, on the evolution of host life history characteristics (e.g. Sousa 1983, Minchella 1985, Thornhill et al. 1986, Forbes 1993, Lafferty 1993, Perrin \& Christe 1996, Combes 2001). Our results contribute to the understanding of both phenotypic plasticity, providing an example of site-induced variation in life history characteristics, and the possible role of parasites in host evolution. Although the potential importance of parasites in life history evolution has received attention, most of this work does not consider inducible responses or plasticity as an outcome (but see Minchella 1985, Forbes 1993, Lafferty 1993). Such a response may exist for Cerithidea scalariformis and perhaps many other species, where risk of parasitism can be relatively high and also variable in space or time.

While the role of parasitism in shaping life history traits remains to be tested for Cerithidea scalariformis, we suggest that plasticity in response to parasitism may be underestimated in host populations. Induced changes in morphology, life history, and behavior (such as habitat utilization) have often been reported as a response to predators, as a strategy to reduce the risk of mortality and increase the chance of successful reproduction (Lively 1986c, Reznick et al. 1990, Tollrian 1995; reviewed in Dodson 1989, Tollrian \& Harvell 1999). In our view, parasitism may often operate in a similar fashion to predation, exerting strong selective pressure for evolutionary change and plasticity, especially for parasites (such as trematodes) that castrate their hosts.

Acknowledgements. We would like to thank S. Reed and $\mathrm{K}$. Rapacon for their tremendous assistance and effort in the field. K. Lafferty provided valuable assistance with the experimental design and B. Steves assisted with the graphics. A. Alldredge, A. Kuris, S. Gaines, and 3 anonymous reviewers provided valuable comments on the manuscript. We would like to especially thank the Smithsonian Marine Station in Ft. Pierce, Florida, for use of their laboratory and computer facilities. St. Lucie County and Indian River Mosquito Control Districts provided access to study sites. Funding was provided by a Graduate Student Malacology Grant from the American Society of Malacologists and by the Smithsonian Marine Station and Link Foundation Graduate Fellowships to N.F.S. This paper represents contribution number 602 of the Smithsonian Marine Station at Fort Pierce.

\section{LITERATURE CITED}

Anderson RM (1978) The regulation of host population growth by parasite species. Parasitology 76:119-157

Anderson RM, May RM (1978) Regulation and stability of host-parasite population interactions. I. Regulatory processes. J Anim Ecol 47:219-247
Behrens Yamada S (1987) Geographic variation in the growth rates of Littorina littorea and L. Saxatilis. Mar Biol 96: 529-534

Behrens Yamada S, Navarrete SA, Needham C (1998) Predation induced changes in behavior and growth rate in three populations of the intertidal snail, Littorina sitkana (Philippi). J Exp Mar Biol Ecol 220:213-226

Berven KA, Gill DE (1983) Interpreting geographic variation in life history traits. Am Zool 23:85-97

Blower S, Roughgarden J (1987) Population dynamics and parasitic castration: a mathematical model. Am Nat 129: $730-753$

Bradshaw AD (1965) Evolutionary significance of phenotypic plasticity in plants. Adv Genet 13:115-155

Brown KM (1979) The adaptive demography of four freshwater pulmonate snails. Evolution 33:417-432

Brown KM (1985) Intraspecific life history variation in a pond snail: the roles of population divergence and phenotypic plasticity. Evolution 39:387-396

Brown KM, Richardson TD (1992) Phenotypic plasticity in the life histories and production of two warm-temperate viviparid prosobranchs. Veliger 35:1-11

Clarke A (1987) Temperature, latitude and reproductive effort. Mar Ecol Prog Ser 38:89-99

Combes C (2001) Parasitism: the ecology and evolution of intimate interactions. University of Chicago Press, Chicago

Curtis LA, Hurd LE (1983) Age, sex, and parasites: spatial heterogeneity in a sandflat population of Ilyanassa obsoleta. Ecology 64:819-828

Day AK, Bayne BL (1988) Allozyme variation in populations of the dog whelk Nucella lapillus (Prosobranchia: Muricacea) from the South West peninsula of England. Mar Biol 99:93-100

DeFreese DE (1995) Land acquisition: a tool for biological diversity protection in the Indian River Lagoon, Florida. Bull Mar Sci 57:14-27

DeWolf H, Backeljau T, Verhagen R (1998) Spatio-temporal genetic structure and gene flow between two distinct shell morphs of the planktonic developing periwinkle Littorina striata (Mollusca: Prosobranchia). Mar Ecol Prog Ser 163: 155-163

Dodson SI (1989) Predator-induced reaction norms - cyclic changes in shape and size can be protective. Bioscience 39:447-452

Fletcher WJ (1984) Intraspecific variation in the population dynamics and growth of the limpet, Cellana tramoserica. Oecologia 63:110-121

Forbes MRL (1993) Parasitism and host reproductive effort. Oikos 67:444-450

Gooch Jl, Smith BS, Knupp D (1972) Regional survey of gene frequencies in the mud snail Nassarius obsoletus. Biol Bull (Woods Hole) 152:36-48

Harvell CD (1984) Predator-induced defense in a marine bryozoan. Science 224:1357-1359

Holliman RB (1961) Larval trematodes from the Apalachee Bay area, Florida, with a checklist of known cercariae arranged in a key to their superfamilies. Tulane Stud Zool 9:1-74

Houbrick RS (1984) Revision of higher taxa in genus Cerithidea (Mesogastropoda: Potamididae) based on comparative morphology and biological data. Am Malacol Bull 2:1-20

Hudson PJ, Newborn D, Dobson AP (1992) Regulation and stability of a free-living host-parasite system: Trichostrongylus tenuis in red grouse. I. Monitoring and parasite reduction experiments. J Anim Ecol 61:477-486

Janson K (1982) Genetic and environmental effects on the growth rates of Littorina saxatilis. Mar Biol 69:73-78 
Janson K, Ward RD (1984) Microgeographic variation in allozyme and shell characters in Littorina saxatilis Olivi (Prosobranchia: Littorinidae). Biol J Linn Soc 22:289-307

Johannesson K, Johannesson B, Rolàn-Alvarez E (1993) Morphological differentiation and genetic cohesiveness over microenvironmental gradient in the marine snail Littorina saxatilis. Evolution 47:1770-1787

Johannesson K, Rolàn-Alverez E, Erlandsson J (1997) Growth rate differences between upper and lower shore ecotypes of the marine snail Littorina saxatilis (Olivi) (Gastropoda). Biol J Linn Soc 61:267-279

Kautsky N (1982) Growth and size structure in a Baltic Mytilus edulis population. Mar Biol 68:117-133

Kuris AM (1974) Trophic interactions: similarity of parasitic castrators to parasitoids. Q Rev Biol 49:129-148

Lafferty KD (1993) The marine snail, Cerithidea californica, matures at smaller sizes where parasitism is high. Oikos 68:3-11

Largen MJ (1967) The influence of water temperature upon the life of the dogwhelk Thais lapillus (Gastropoda: Prosobranchia). J Anim Ecol 36:207-214

Levins R (1968) Evolution in changing environments. Princeton University Press, Princeton, NJ

Lewis JR, Bowman RS (1975) Local habitat-induced variations in the population dynamics of Patella vulgata L. J Exp Mar Biol Ecol 17:165-203

Lively CM (1986a) Canalization versus developmental conversion in a spatially-variable environment. Am Nat 128: 561-572

Lively CM (1986b) Competition, comparative life histories, and maintenance of shell dimorphism in a barnacle. Ecology 67:858-864

Lively CM (1986c) Predator-induced shell dimorphism in the acorn barnacle, Chthamalus anisopoma. Evolution 40: $232-242$

Lively CM, Hazel WN, Schellenberger MJ, Michelson KS (2000) Predator-induced defense: variation for inducibility in an intertidal barnacle. Ecology 81:1240-1247

MacDonald BA, Thompson RJ (1985) Influence of temperature and food availability on the ecological energetics of the giant scallop Placopecten magelanicus. I. Growth rates of shell and somatic tissue. Mar Ecol Prog Ser 25:279-294

Margolis L, Esch GW, Holmes JC, Kuris AM, Schad GM (1982) The use of ecological terms in parasitology (report of an ad hoc committee of the American Society of Parasitologists). J Parasitol 68:131-133

McNeff L (1978) Marine cercariae from Cerithidea pliculosa Menke from Dauphin Island, Alabama; life cycles of heterophyid and opisthorchiid Digenea from Cerithidea Swainson from the Eastern Gulf of Mexico. MSc thesis, University of Alabama, Mobile

Medvedev ZA (1990) An attempt at a rational classification of theories on aging. Biol Rev 65:375-398

Minchella DJ (1985) Host life history variation in response to parasitism. Parasitology 90:205-216

Moore HB (1936) The biology of Purpura lapillus. I. Shell variation in relation to environment. J Mar Biol Assoc UK 21: 61-89

Palumbi SR (1995) Using genetics as an indirect estimator of larval dispersal. In: McEdward L (ed) Ecology of marine invertebrate larvae. CRC Press, Boca Raton, FL, p 369-387

Parry GD (1978) Effects of growth and temperature acclimation on metabolic rate in the limpet, Cellana tramoserica (Gastropoda: Patellidae). J Anim Ecol 47:351-368

Parry GD (1982) The evolution of the life histories of four species of intertidal limpets. Ecol Monogr 52:65-91
Parsons KE (1998) The role of dispersal ability in the phenotypic differentiation and plasticity of two marine gastropods. II. Growth. J Exp Mar Biol Ecol 221:1-25

Perrin N, Christe P (1996) On host life history response to parasitism. Oikos 75:317-320

Phillips BF, Campbell NA, Wilson BR (1973) A multivariate study of geographic variation in the whelk Dicathais. J Exp Mar Biol Ecol 11:27-69

Rey JR, Kain T (1989) A guide to the salt marsh impoundments of Florida. Florida Entomology Laboratory, Vero Beach, FL

Reznick D, Endler JA (1982) The impact of predation on life history evolution in trinidadian guppies (Poecilia reticulata). Evolution 36:160-177

Reznick DA, Bryga H, Endler JA (1990) Experimentally induced life history evolution in a natural population. Nature 36:357-359

Roberts DJ, Hughes RN (1980) Growth and reproductive rates of Littorina rudis from three contrasted shores in North Wales, UK. Mar Biol 58:47-54

Rolan E, Guerra-Varela J, Colson I, Hughes RN, RolanAlvarez E (2004) Morphological and genetic analysis of two sympatric morphs of the dogwhelk Nucella lapillus (Gastropoda: Muricidae) from Galicia (northern Spain). J Molluscan Stud 70:179-185

Rothschild M (1941) The effect of trematode parasites on the growth of Littorina neritoides (L.). J Mar Biol Assoc UK 25: 69-80

Ruiz GM (1991) Consequences of parasitism to marine invertebrates: host evolution? Am Zool 31:831-839

Ruiz GM, Lindberg DR (1989) A fossil record for trematodes: extent and potential uses. Lethaia 22:431-438

Scheltema RS (1971) Larval dispersal as a means of genetic exchange between geographically separated populations of shallow-water benthic marine gastropods. Biol Bull (Woods Hole) 140:284-322

Schlichting CD (1986) The evolution of phenotypic plasticity in plants. Annu Rev Ecol Syst 17:667-693

Schmalzer PA (1995) Biodiversity of saline and brackish marshes of the Indian River Lagoon: historic and current patterns. Bull Mar Sci 57:37-48

Smith NF (2001) Spatial heterogeneity in recruitment of larval trematodes to snail intermediate hosts. Oecologia 127: $115-122$

Sousa WP (1983) Host life history and the effect of parasitic castration on growth: a field study of Cerithidea californica Haldeman (Gastropoda: Prosobranchia) and its trematode parasites. J Exp Mar Biol Ecol 73:273-296

Spight TM (1973) Ontogeny, environment, and shape of a marine snail Thais lamellosa Gmelin. J Exp Mar Biol Ecol 13:215-228

Staiger H (1957) Genetic and morphological variation in Purpura lapillus with respect to local and regional differentiation in population groups. Année Biol 33:251-258

Stearns SC (1976) Life history tactics: a review of ideas. Q Rev Biol 51:3-47

Stearns SC (1989a) The evolutionary significance of phenotypic plasticity. Bioscience 39:436-446

Stearns SC (1989b) Trade-offs in life history evolution. Funct Ecol 3:259-268

Stearns SC (1992) The evolution of life histories. Oxford University Press, New York

Struhsaker JW (1968) Selection mechanisms associated with intraspecific shell variation in Littorina picta (Prosobranchia: Mesogastropoda). Evolution 22:459-480

Sutherland JP (1970) Dynamics of high and low populations of the limpet, Acmaea scabra (Gould). Ecol Monogr 40: 169-188 
Taylor BE, Gabriel W (1992) To grow or not to grow: optimal resource allocation for Daphnia. Am Nat 139:248-266

Thornhill JA, Jones JT, Kusel JR (1986) Increased oviposition and growth in immature Biomphalaria glabrata after exposure to Schistosoma mansoni. Parasitology 93:443-450

Tollrian R (1995) Predator-induced morphological defenses: costs, life history shifts, and maternal effects in Daphnia pulex. Ecology 76:1691-1705

Tollrian R, Harvell CD (eds) (1999) The ecology and evolution of inducible defenses. Princeton University Press, Princeton, NJ

Travis J (1983) Variation in development patterns of larval anurans in temporary ponds. I. Persistent variation within a Hyla gratiosa population. Evolution 37:496-512

Trowbridge CD (1994) Life at the edge: population dynamics

Editorial responsibility: Otto Kinne (Editor),

Oldendorf/Luhe, Germany and salinity tolerance of a high intertidal, pool-dwelling ascoglossan opithobranch on New Zealand rock shores. J Exp Mar Biol Ecol 182:65-84

Trussell GC (1997) Phenotypic plasticity in the foot size of an intertidal snail. Ecology 78:1033-1048

Trussell GC, Smith LD (2000) Induced defenses in response to an invading crab predator: an explanation of historical and geographic phenotypic change. Proc Natl Acad Sci (USA) 97:2123-2127

Underwood AJ (1979) The ecology of intertidal gastropods. Adv Mar Biol 16:111-210

Vermeij GT (1993) A natural history of shells. Princeton University Press, Princeton, NJ

Vilas CN, Vilas NR (1970) Florida marine shells. Charles E. Tuttle, Tokyo

Submitted: June 4, 2004; Accepted: September 7, 2004 Proofs received from author(s): December 16, 2004 